\title{
Biodiversity of Microinvertebrates coinhabiting mosquitoes habitats in patchy rock pools on inselbergs within Kaduna State, Nigeria
}

Okechukwu Anthony Obi ${ }^{1^{*}}$, Ishaya Haruna Nock² and David Adeyinka Adebote ${ }^{2}$

\begin{abstract}
Background: Interaction of microinvertebrates with mosquito in freshwater ecosystem ultimately provides the mosquito larvae with diverse resources to prey on and serves as competitors or predators. The trophic ecology and productivity of mosquito larvae in rock pool habitats are paramount to modelling and predicting adult mosquito abundance and ultimately limit their disease spread.

Results: Fine mesh plankton net and soup ladle dipper were used to obtain microinvertebrates and preimaginal mosquitoes respectively in 368 rock pools on inselbergs in 21 settlements within Kaduna State, Nigeria. A total of 31,726 mosquito larvae bred in 269 rock pools coinhabited with microinvertebrates. Diluted ethanol (70\%) and formaldehyde (4\%) were used to preserve mosquito and microinvertebrate specimens, respectively. Specimens of mosquito larvae and microinvertebrates were identified using standard keys. Pearson's correlation analysis was used to establish the relationship between abundances of mosquitoes and microinvertebrates. Thirty species of microinvertebrates coinhabited with six species of mosquito (Aedes vittatus, Anopheles gambiae s.l., Culex macfiei, Cx. perfidiosus, Cx. pipiens pipiens, and $(x$. simpsoni). The microinvertabrates included the protozoans: Paramecium caudatum (Parameciidae) and Pleurotricha sp. (Oxytrichidae); Chlamydomonas reinhardtii; the rotifers: Brachionus plicatilis (Brachionidae) and Philodina sp. (Philodinidae); the sponge (Porifera): Heteromeyenia tenosperma (Spongillidae); the crustaceans: Ephemeroporous barroisi (Chydoridae), Bosmina longirostris (Bosminidae), Daphnia pulex (Daphniidae), Diaphanosoma birgei (Sididae), Diaphanosoma brachyurum, Laptonopsis occidentalis, Macrothrix pulex (Macrothricidae), Macrothrix rosea, Moinodaphnia macleayi (Moinidae), Moina macrocopa (Moinidae), Sida crystallina (Sididae), Bradleystrandesia reticulata (Cyprididae), Candona intermedia (Candonidae), Candona parallela, Cypria obesa (Cyprididae), Heterocyp.ris incongruens (Cyprididae), Potamocypris hyboforma (Cyprididae), Cyclops sp. (Cyclopidae), and Macrocyclops sp. (Cyclopidae); and the nematodes: Alaimus sp. (Alaimidae), Diplogaster sp. (Diplogasteridae), Monhystera sp. (Monhysteridae), and Rhabdolaimus sp. (Rhabdolaimidae). Mosquitoes relative abundance correlated negatively but significantly $(P<0.05)$ with those of the microinvertebrates. Analysis of variance (ANOVA) shows that the abundance of mosquito larvae significantly differed with $\mathrm{pH}$ of the rock pools $(P<0.05)$. Highly significant difference existed with the abundance of mosquito larvae to total dissolved solid, electrical conductivity, and alkalinity of the rock pools $(P<0.001)$.

Conclusions: These microinvertebrates constituted mosquito food organisms and/or natural antagonists as competitors for food, intraguild, or strict predators that would have influenced mosquito organization in a complex feeding web in the communities.
\end{abstract}

Keywords: Microinvertebrates, Mosquitoes, Coinhabitation, Rock pools, Inselbergs, Physicochemical parameters

\footnotetext{
* Correspondence: okeyobi1160@yahoo.com

'Department of Zoology, Federal University of Agriculture, Makurdi, Benue

State, Nigeria

Full list of author information is available at the end of the article
} 


\section{Background}

Amongst the most important determinants of adult mosquito abundance and distribution is the presence and quality of larval habitats. Mosquitoes which are medically the most important group of insects, both in number of disease agents they transmit and the magnitude of health problems, play an important role in the ecological food chain (Merritt, Dadd, \& Walker, 1992). Given their roles as vectors for diseases such as malaria, yellow fever, dengue, and West Nile virus, they continue to have a considerable impact on human societies (Rueda, 2007). Approximately $40 \%$ of mosquito species develop in small natural or artificial habitats that are periodically filled with rainwater or plant exudates (Kaufman, Goodfriend, Kohler-Garrigan, Walker, \& Klug, 2002). Their reproduction can be successful only if larval habitats remain stable for a duration equivalent to the development of immature stages (Pialoux, Gaüzère, Jauréguiberry, \& Strobel, 2007). Larval densities are controlled by interactions between abiotic (hydrology, temperature, light/shade, $\mathrm{pH}$, salinity, nutrient availability) and biotic (predation, competition) factors (Yee, Kesavaraju, \& Juliano, 2004). The choice for suitable places for female mosquitoes to lay eggs is a key factor for the survival of immature stages, and this oviposition site selection has been recognized as critical both for the survival and population dynamics of mosquitoes. It is influenced by several environmental factors including the salinity and turbidity of the water, the size and degree of permanence of the water body, the amount of sunlight, the presence of emergent/floating vegetation and shade, the presence of predators, and the distance to human habitation (Pialoux et al., 2007; Yee et al., 2004).

Several studies have shown that community structure and variations in mosquito abundances can be explained by predation which is the most important biological interactions in aquatic environments and thus a major force in shaping freshwater communities (Chase \& Knight, 2003; Fischer, Zanotti, Castro, Quiroga, \& Vargas, 2013). The composition of the mosquito community found in a water body is a result of the oviposition behaviour of the species (Andrade, 2015). Ovipositing insects select sites that improve the survival, growth, and reproductive potential of the offspring, especially for species in which juveniles are incapable of migrating away from low-quality habitats (Andrade, 2015) and most of the population regulation processes occur during immature stages (Chase \& Knight, 2003). Mosquito larvae have evolved different filtering mechanisms and morphological adaptations which provide behavioural flexibility for feeding on diverse resources (Andrade, 2015; Merritt et al., 1992). Mosquito larvae feed on organic matter from the environment, notably plant debris, crustaceans, and insect scales as well as microorganisms including algae, protozoa, and bacteria (Linenberg, Christophides, \& Gendrin, 2016). Mosquito nutritional requirements are met through the consumption of both dead and living organic material. Thus, spatial variation in biotic interactions can explain spatial variation in larval mosquito densities. The knowledge of trophic ecology and productivity of mosquito larvae in rock pool habitats is paramount to modelling and predicting adult mosquito abundance and ultimately limit their disease spread. This study therefore aimed at elucidating the ecological undertone existing between microinvertebrates and larval mosquitoes coinhabiting patchy rock pools on inselbergs within Kaduna State.

\section{Materials and methods}

\section{Study area and sites}

This study was carried out on the rocky hills of the Kaduna State located between Lat $8^{\circ} 30^{\prime} 0^{\prime \prime} \mathrm{N}$ and $11^{\circ}$ $30^{\prime} 0^{\prime} \mathrm{N}$ and Long $6^{\circ} 0^{\prime} 0^{\prime} \mathrm{E}$ and $8^{\circ} 30^{\prime} 0^{\prime \prime} \mathrm{E}$, Northern Nigeria (Fig. 1). Kaduna State is the fourth most populous state in the federation and represents a major focus and centre of political and economic activities in the nation (NPC, 2006). The State occupies an area of approximately $48,473.2 \mathrm{~km}^{2}$ and has a population of 6 , 113,503 and a population density of 130 people per square kilometre. It accounts for $4.3 \%$ of Nigeria's total population (NPC, 2006). There are two marked seasons in the state, a dry windy season and a rainy (wet) season. The wet season is usually from April to October with great variations as one move northwards (Nigerian Arts and Culture Directory Project, 2013). Sampling locations consisted of nine local government areas out of the 23 local government areas of the state. The southern Guinea savanna parts of the state that were sampled included the following local government areas: Jaba, Jema'a, Kagarko, Kajuru, Kaduna-North, Igabi, and Giwa (partly Guinea and partly Sudan savanna) in the following settlements: Kwoi, Nok, Samban-Gida, Kagoma, Chori, Kagarko, Jere, Tudun-Mare, Kufana, Kajuru, Kujama, Baban-Sora, Malali, Kangimi, and Kufena. In Sudan savanna, Sabon-Gari local government area was sampled only in Hanwa settlement. Danmagaji, Wusasa, Dutsen-Abba, Dumbi, and Zango-Aya settlements were sampled in Zaria local government area.

\section{Study duration and determination of geographic coordinates}

The study was conducted for 5 months between June and October 2013. Available true rock pools were searched fortnightly on the inselbergs as much as access permitted, assisted by the local community members. A GARMIN eTrex Venture HC handheld global positioning system (GPS) was used to determine the geographic coordinates, altitude above sea level, and altitude above 


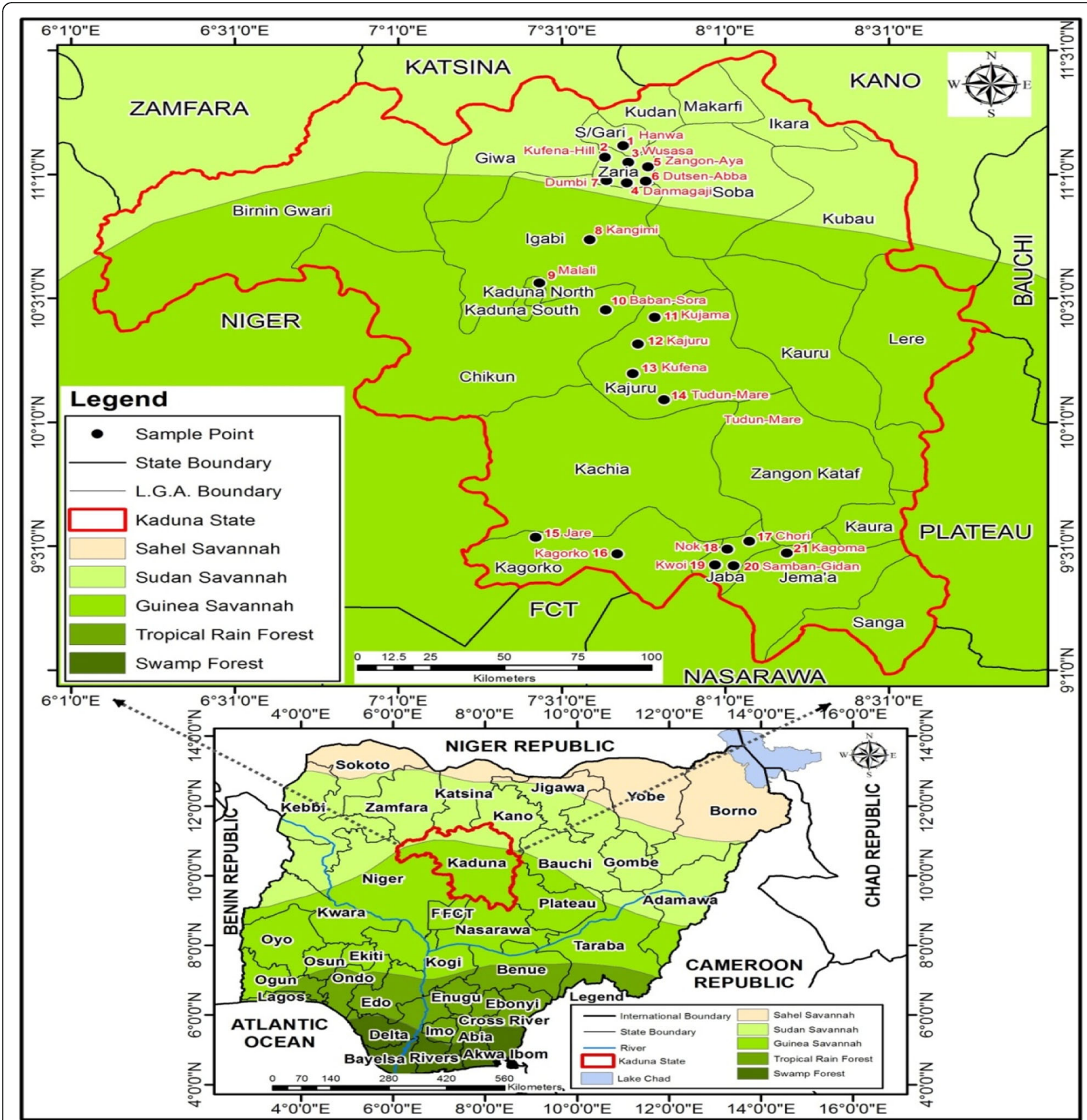

Fig. 1 Kaduna State showing sampling locations

the surroundings of the rock pools in the settlements across the state.

\section{Sampling and specimen preservation techniques}

Samplings were carried out fortnightly in the Guinea and Sudan savanna parts of the state for a period of 5 months. Available rock pools were sampled for microinvertebrates coinhabiting mosquito breeding microhabitats in 21 settlements within Kaduna State. Ten dips of water in every other rock pool were obtained with a plastic soup ladle dipper (0.105 l capacity) (Service, M. W., 1976. Water from each pool was collected in a white plastic bowl and carefully observed for the presence of preimaginal mosquitoes. Anopheline larvae were collected alive into plastic bottles, transported to the laboratory, and reared to adults in small plastic bowls $(11 \times 5.5 \mathrm{~cm})$ on a diet of bakers' yeast (Service, M. W. 1992). Culicine larvae, in their fourth instar, were concentrated in a sieve, carefully picked with dropping pipette into labelled specimen bottles, and preserved in $70 \%$ 
ethanol. Culicine larvae in their lower instars were nurtured to the fourth instar in labelled plastic bowls on a diet of bakers yeast and subsequently preserved in 70\% ethanol in appropriately labelled specimen bottles. The microinvertebrates within each pool were sampled using a fine mesh invertebrate net. They were sorted and preserved in $4 \%$ formaldehyde in appropriately labelled specimen bottles.

\section{Determination of physicochemical parameters of rock pools}

The mean depth of water in each rock pool was determined by dipping a metal rod to touch the bottom of the pool at three locations and the wet region of the rod measured against a transparent ruler. The mean of the three measurements was taken to determine the mean depth of each rock pool. The surface areas of rock pools were determined with a metre rule to measure the length and width of each pool after making the necessary adjustment for irregular surfaces according to the method Adebote, Oniye, \& Muhammed, 2008. The area of each pool was then calculated. The $\mathrm{pH}$, electrical conductivity, total dissolved solids, and temperature of water in each rock pool were determined by means of a HANNA HI 98129 pH/EC/TDS/Temp metre. Other parameters, which included turbidity, total alkalinity, total suspended solids, total hardness, dissolved oxygen, biological oxygen demand, chemical oxygen demand, phosphate, and nitrate, were determined according to the standard protocols described by the American Public Health Association (1998).

\section{Species identification}

All the mosquitoes collected were morphologically identified to the species taxon and counted under the $\times 50$ magnification of a stereo microscope. Anopheline mosquitoes were identified based on the pictorial keys of Gillies and Coetzee (1987) and Gillies and DeMeillon (1968). Culicine mosquitoes were identified based on the pictorial keys of Hopkins (1952). Microinvertebrate fauna isolated from the rock pools was identified microscopically to species using the identification keys in Pennak (1953).

\section{Data analysis}

Pearson's correlation analysis was used to establish relationships between the physicochemical parameters of water, biota abundance in rock pools, and abundance of species of mosquito breeding therein. Principal component analysis (PCA) was used to examine the relationships (interaction effects) amongst physicochemical parameters of water and to select water parameters that were most useful in distinguishing mosquito species habitats in rock pools. One-way analysis of variance
(ANOVA) was employed to test for significant differences of physicochemical factors in relation to mosquito abundance, using the least significant difference to separate means that differed significantly. All levels of statistical significance were determined at $P<0.05$.

\section{Results}

Ecological studies into the diversity of microinvertebrate fauna coinhabiting mosquitoes habitats were conducted in 368 rock pools on inselbergs in 21 settlements within Kaduna State. Two hundred and sixty-nine rock pools consisted of the natural community of mosquito larvae with a total of 31,726 mosquito larvae (Table 1). The height of the inselbergs varied from 597 to $811 \mathrm{~m}$ above sea level. The relative abundance and density of mosquito larvae per pool were relatively high in all the inselbergs except on Kufana inselberg that recorded zero abundance of mosquito larva. Rock pools were found to habour 30 different species of microinvertebrates coinhabited with the three main genera (Aedes, Anopheles, and Culex) of mosquito larvae predominated by cladocerans (Table 2). Daphnia pulex preponderates more than any other cladocerans in mosquito larval breeding water pockets. Three main genera (Aedes, Anopheles, and Culex) of mosquito larvae coinhabited with Daphnia pulex in a magnitude that is next to Monhystera sp. (nematode). Ostracods occur as the next higher class of crustaceans and amongst the diversity of microinvertebrates that occur in rock pools on inselbergs. Candona parallela (ostracod), although not in abundance compare with Cypricercus reticulatus, coinhabited with the highest number of heterogeneric species of mosquito larvae in their breeding water pockets. Although nematodes were amongst the least class of microinvertebrate diversity, Monhystera sp. by far outweighs all the microinvertebrates in a number of identified species. Allocrangonyx pellucidus (sideswimmers), Brachionus plicatilis (rotifers) Candona intermedia (seed shrimps), Diaphnosoma birgei (water fleas), Diaphnosoma brachyurum (water fleas), Heteromeyenia tenosperma (sponges), Macrothrix pulex (water fleas), Moinodaphnia macleayi (water fleas), Pleurotricha sp. (protozoan), and Rhabdolaimus sp. (nematode) were least found with mosquito larvae in rock pools. Diplogaster sp. (nematode) and Chydorus barroisi (water flea) were observed only in rock pools without mosquito larva. Although microinvertebrates correlated negatively $(r=-0.049)$ with mosquito abundance, malaria vectors were found largely in rock pools dominated by these organisms. The physicochemical parameters of the rock pools utilized by six species of mosquitoes coinhabited with microinvertebrates are shown in Table 3. Aedes vittatus bred in pools with the shallowest depth and consequently associated with the extreme range of temperature. Culex simpsoni 
Table 1 Occurrence and abundance of mosquito larvae in rock pools on inselbergs in Kaduna State, Nigeria

\begin{tabular}{|c|c|c|c|c|c|c|c|}
\hline $\begin{array}{l}\text { Inselbergs } \\
\text { (coordinates) }\end{array}$ & $\begin{array}{l}\text { Altitude above } \\
\text { sea level }(m)\end{array}$ & $\begin{array}{l}\text { Height above } \\
\text { surrounding area (m) }\end{array}$ & $\begin{array}{l}\text { No. of pools } \\
\text { examined }\end{array}$ & $\begin{array}{l}\text { No. of pools } \\
\text { positive (\%) }\end{array}$ & $\begin{array}{l}\text { No. of larvae } \\
\text { collected (\%) }\end{array}$ & $\begin{array}{l}\text { Relative } \\
\text { abundance of } \\
\text { larvae }\end{array}$ & $\begin{array}{l}\text { Larval no. per } \\
\text { pool (density) }\end{array}$ \\
\hline \multicolumn{8}{|l|}{ Sudan savanna } \\
\hline $\begin{array}{c}\text { Danmagaji } \\
\left(11^{\circ} 05^{\prime} 17.9^{\prime \prime} \mathrm{N}\right) \\
\left(07^{\circ} 41^{\prime} 17.2^{\prime \prime} \mathrm{E}\right)\end{array}$ & 676 & 6 & 16 & $8(50.0)$ & $2196(6.9)$ & 274.5 & 137.3 \\
\hline $\begin{array}{l}\text { Dumbi } \\
\left(10^{\circ} 57^{\prime} 33.3^{\prime \prime} \mathrm{N}\right) \\
\left(07^{\circ} 39^{\prime} 16.6^{\prime \prime} \mathrm{E}\right)\end{array}$ & 711 & 9 & 17 & $14(82.4)$ & $1202(3.8)$ & 85.9 & 70.7 \\
\hline $\begin{array}{r}\text { Dutsen-Abba } \\
\left(10^{\circ} 59^{\prime} 26.5^{\prime \prime} \mathrm{N}\right) \\
\left(07^{\circ} 38^{\prime} 52.7^{\prime \prime} \mathrm{E}\right)\end{array}$ & 699 & 15 & 22 & $7(31.8)$ & $314(1.0)$ & 44.9 & 14.3 \\
\hline $\begin{array}{l}\text { Hanwa } \\
\left(11^{\circ} 07^{\prime} 14.2^{\prime \prime} \mathrm{N}\right) \\
\left(07^{\circ} 42^{\prime} 13.4^{\prime \prime} \mathrm{E}\right)\end{array}$ & 677 & 18 & 29 & $25(86.2)$ & $5042(15.9)$ & 201.7 & 173.9 \\
\hline $\begin{array}{l}\text { Kufena } \\
\left(11^{\circ} 05^{\prime} 08.5^{\prime \prime} \mathrm{N}\right) \\
\left(07^{\circ} 39^{\prime} 35.4^{\prime \prime} \mathrm{E}\right)\end{array}$ & 718 & 36 & 29 & $18(62.1)$ & $1086(3.4)$ & 60.3 & 37.4 \\
\hline $\begin{array}{l}\text { Wusasa } \\
\left(11^{\circ} 04^{\prime} 36.1^{\prime \prime} \mathrm{N}\right) \\
\left(07^{\circ} 40^{\prime} 28.5^{\prime \prime} \mathrm{E}\right)\end{array}$ & 699 & 18 & 8 & $6(75.0)$ & 4210 (13.3) & 701.7 & 526.3 \\
\hline $\begin{array}{c}\text { Zango-Aya } \\
\left(10^{\circ} 53^{\prime} 14.6^{\prime \prime} \mathrm{N}\right) \\
\left(07^{\circ} 38^{\prime} 43.9^{\prime \prime} \mathrm{E}\right)\end{array}$ & 750 & 49 & 37 & $25(67.6)$ & $1200(3.8)$ & 48.0 & 32.4 \\
\hline \multicolumn{8}{|l|}{ Guinea savanna } \\
\hline $\begin{array}{c}\text { Baban-Sora } \\
\left(10^{\circ} 30^{\prime} 23.6^{\prime \prime} \mathrm{N}\right) \\
\left(07^{\circ} 27^{\prime} 51.7^{\prime \prime} \mathrm{E}\right)\end{array}$ & 602 & 20 & 10 & $8(80.0)$ & $1636(5.2)$ & 204.5 & 163.6 \\
\hline $\begin{array}{l}\text { Chori } \\
\left(09^{\circ} 30^{\prime} 58.1^{\prime \prime} \mathrm{N}\right) \\
\left(08^{\circ} 01^{\prime} 54.4^{\prime \prime} \mathrm{E}\right)\end{array}$ & 760 & 17 & 15 & $13(86.7)$ & $656(2.1)$ & 50.5 & 43.7 \\
\hline $\begin{array}{l}\text { Jere } \\
\left(09^{\circ} 34^{\prime} 03.5^{\prime \prime} \mathrm{N}\right) \\
\left(07^{\circ} 25^{\prime} 48.0^{\prime \prime} \mathrm{E}\right)\end{array}$ & 597 & 35 & 21 & $20(95.2)$ & 2664 (8.4) & 133.2 & 126.9 \\
\hline $\begin{array}{c}\text { Kagarko } \\
\left(09^{\circ} 29^{\prime} 08.3^{\prime \prime} \mathrm{N}\right) \\
\left(07^{\circ} 41^{\prime} 50.1^{\prime \prime} \mathrm{E}\right)\end{array}$ & 680 & 16 & 10 & $8(80.0)$ & $869(2.7)$ & 108.6 & 86.9 \\
\hline $\begin{array}{c}\text { Kagoma } \\
\left(09^{\circ} 27^{\prime} 46.1^{\prime \prime} \mathrm{N}\right) \\
\left(08^{\circ} 05^{\prime} 24.0^{\prime \prime} \mathrm{E}\right)\end{array}$ & 804 & 16 & 22 & $18(81.8)$ & $812(2.6)$ & 45.1 & 36.9 \\
\hline $\begin{array}{l}\text { Kajuru } \\
\left(10^{\circ} 19^{\prime} 14.9^{\prime \prime} \mathrm{N}\right) \\
\left(07^{\circ} 41^{\prime} 02.4^{\prime \prime} \mathrm{E}\right)\end{array}$ & 732 & 47 & 21 & $14(66.7)$ & $1309(4.1)$ & 93.5 & 62.3 \\
\hline $\begin{array}{c}\text { Kangimi } \\
\left(10^{\circ} 43^{\prime} 13.9^{\prime \prime} \mathrm{N}\right) \\
\left(07^{\circ} 34^{\prime} 17.4^{\prime \prime} \mathrm{E}\right)\end{array}$ & 656 & 4 & 24 & 21 (87.5) & $1442(4.5)$ & 68.7 & 60.1 \\
\hline $\begin{array}{l}\text { Kufana } \\
\left(10^{\circ} 19^{\prime} 18.6^{\prime \prime} \mathrm{N}\right) \\
\left(07^{\circ} 44^{\prime} 54.5^{\prime \prime} \mathrm{E}\right)\end{array}$ & 765 & 48 & 6 & $0(0.0)$ & $0(0.0)$ & 0.0 & 0.0 \\
\hline $\begin{array}{l}\text { Kujama } \\
\left(10^{\circ} 28^{\prime} 23.7^{\prime \prime} \mathrm{N}\right) \\
\left(07^{\circ} 37^{\prime} 29.3^{\prime \prime} \mathrm{E}\right)\end{array}$ & 736 & 76 & 16 & $11(68.8)$ & $1429(4.5)$ & 129.9 & 89.3 \\
\hline $\begin{array}{l}\text { Kwoi } \\
\left(09^{\circ} 27^{\prime} 12.9^{\prime \prime} \mathrm{N}\right) \\
\left(08^{\circ} 00^{\prime} 53.4^{\prime \prime} \mathrm{E}\right)\end{array}$ & 794 & 14 & 16 & $11(68.8)$ & $911(2.9)$ & 82.8 & 56.9 \\
\hline $\begin{array}{l}\text { Malali } \\
\left(10^{\circ} 32^{\prime} 41.8^{\prime \prime} \mathrm{N}\right) \\
\left(07^{\circ} 28^{\prime} 15.9^{\prime \prime} \mathrm{E}\right)\end{array}$ & 616 & 18 & 10 & $10(100.0)$ & 3476 (11.0) & 347.6 & 347.6 \\
\hline
\end{tabular}


Table 1 Occurrence and abundance of mosquito larvae in rock pools on inselbergs in Kaduna State, Nigeria (Continued)

\begin{tabular}{|c|c|c|c|c|c|c|c|}
\hline $\begin{array}{l}\text { Inselbergs } \\
\text { (coordinates) }\end{array}$ & $\begin{array}{l}\text { Altitude above } \\
\text { sea level }(\mathrm{m})\end{array}$ & $\begin{array}{l}\text { Height above } \\
\text { surrounding area (m) }\end{array}$ & $\begin{array}{l}\text { No. of pools } \\
\text { examined }\end{array}$ & $\begin{array}{l}\text { No. of pools } \\
\text { positive (\%) }\end{array}$ & $\begin{array}{l}\text { No. of larvae } \\
\text { collected (\%) }\end{array}$ & $\begin{array}{l}\text { Relative } \\
\text { abundance of } \\
\text { larvae }\end{array}$ & $\begin{array}{l}\text { Larval no. per } \\
\text { pool (density) }\end{array}$ \\
\hline $\begin{array}{l}\text { Nok } \\
\left(09^{\circ} 28^{\prime} 46.3^{\prime \prime} \mathrm{N}\right) \\
\left(08^{\circ} 01^{\prime} 19.3^{\prime \prime} \mathrm{E}\right)\end{array}$ & 811 & 67 & 14 & $8(57.1)$ & $242(0.8)$ & 30.3 & 17.3 \\
\hline $\begin{array}{r}\text { Samban-Gida } \\
\left(09^{\circ} 27^{\prime} 06.4^{\prime \prime} \mathrm{N}\right) \\
\left(08^{\circ} 03^{\prime} 10.7^{\prime \prime} \mathrm{E}\right)\end{array}$ & 798 & 24 & 20 & $13(65.0)$ & 706 (2.2) & 54.3 & 35.3 \\
\hline $\begin{array}{c}\text { Tudun-Mare } \\
\left(10^{\circ} 19^{\prime} 15.0^{\prime \prime} \mathrm{N}\right) \\
\left(07^{\circ} 42^{\prime} 57.4^{\prime \prime} \mathrm{E}\right)\end{array}$ & 722 & 22 & 23 & $11(47.8)$ & $324(1.0)$ & 29.5 & 14.1 \\
\hline Total & & & 386 & 269 (69.7) & 31,726 & 117.9 & 82.2 \\
\hline
\end{tabular}

bred in pool with the deepest depth. Culex macfiei bred in pools with broad range of surface area. $\mathrm{pH}$ of the rock pools varied from neutral $(\mathrm{pH} 7.05)$ to strong alkalinity ( $\mathrm{pH} 12.69)$. Culex macfiei amongst other culicines bred in pools with the strongest range of alkalinity (pH 10.32-12.19). Analysis of variance (ANOVA) shows that the abundance of mosquito larvae differed significantly with $\mathrm{pH}$ of the rock pools $(P<0.05)$. Highly significant difference existed in the abundance of mosquito larvae to total dissolved solid, electrical conductivity, and alkalinity of the rock pools $(P<0.001)$. Weak positive correlation existed between dissolved oxygen $(r=0.394)$ and abundance of mosquito larvae while strong positive correlation exists between biochemical oxygen demand $(r=1.000)$ and the abundance of mosquito larvae. Principal component analysis (PCA) shows that the interaction effect of physicochemical parameters of breeding microhabitats of mosquitoes is largely similar and negatively correlated with the study locations (Fig. 2). Temperature, electrical conductivity, and total dissolved solid strongly correlated $(P<$ $0.05)$ with the abundance of mosquito larvae in rock pools on Dumbi inselberg while nitrate and turbidity were vital in influencing mosquito breeding on Hanwa inselberg. Water hardness also correlated strongly $(P<0.05)$ with the abundance of mosquito larvae on Kufena inselberg. The colonization of mosquitoes in rock pools on inselbergs did not significantly correlate with dissolved oxygen, biochemical oxygen demand, chemical oxygen demand, and $\mathrm{pH}$ $(P>0.05)$.

\section{Discussion}

This study demonstrated that rock pools provided natural conditions for mosquitoes to colonize and interact competitively with microinvertebrates that could serve as food organisms and/or possible predators. The microinvertebrates were largely dominated by cladocerans which are common species in all types of freshwater pools. They are found in nearly all types of pond and could be used as agents for mosquito control without disturbing the natural biotope fauna (Kroeger, Liess, Dziock, \& Duquesne, 2013). This is arguably supported with their tremendous adaptive diversity to successfully colonize the rock pools. This study corroborates with several previous investigations which have shown the negative impact of cladocerans on populations of mosquito larvae (Beketov, Yurchenko, Belevich, \& Liess, 2010; Chase \& Knight, 2003; Meyabeme Elono, Liess, \& Duquesne, 2010). In previous studies, Liess, Kroeger, and Duquesne (2014) noted a strong negative impact of Ostracoda on the development of mosquito larval populations compared to Cladocera. Although cladocerans diversify more than any other microinvertebrates, they presumably have had no positive impact on populations of mosquito larvae, hence the high abundance and larval density of mosquito larvae per pool. The polyphagous activities of one of the major controphic competitors of mosquito larvae, cladocerans, and major predators, ostracods, could probably explain the reason for abundance of mosquito larvae despite their coinhabitation in rock pools. Indeed, previous studies have indicated that Ostracoda are both predators and food competitors for mosquito larvae (Liess et al., 2014) while Copepoda are omnivorous filter feeders that consume mostly largesized food particles. Another possible reason for preponderance of mosquito larvae in rock pools could also be due to share of common predators which will limit prey availability. This probably in turn offers mosquito larvae the opportunity to develop to pupal and adult stages. In contrast, Duquesne, Kroeger, Kutyniok, and Liess (2011) contend that both the oviposition and the development of $C x$. pipiens larvae were reduced more in the presence of high densities of cladocerans than in the presence of low densities. Kroeger et al. (2013) affirmed that established population of $D$. magna affected both the oviposition and the larval development of $C x$. pipiens negatively as well as time to metamorphosis and the size of larvae at the time of metamorphosis. 
Table 2 Microinvertebrates coinhabiting mosquito habitats in rock pools on inselbergs within Kaduna State, Nigeria

\begin{tabular}{|c|c|c|c|c|c|c|}
\hline \multirow{2}{*}{$\begin{array}{l}\text { Microinvertebrate } \\
\text { species }\end{array}$} & \multicolumn{5}{|c|}{ No. collected(\%) } & \multirow{2}{*}{$\begin{array}{l}\text { No. of associated mosquito } \\
\text { species (abbreviated) }\end{array}$} \\
\hline & Class/order & $\begin{array}{l}\text { Microinvertebrates in } \\
\text { mosquito-positive pools }\end{array}$ & $\begin{array}{l}\text { Microinvertebrates in } \\
\text { mosquito-negative pools }\end{array}$ & Total & $\begin{array}{l}\text { No. of inselbergs } \\
\text { where found }\end{array}$ & \\
\hline $\begin{array}{l}\text { Heteromeyenia } \\
\text { tenosperma }\end{array}$ & Porifera & $1(50.0)$ & $1(50.0)$ & 2 & 2 & 1 (Ae. vitt) \\
\hline $\begin{array}{l}\text { Chlamydomonas } \\
\text { reinhardtii }\end{array}$ & Protozoa & $5(83.3)$ & $1(16.7)$ & 6 & 2 & 2 (Ae. vitt., Cx. perf.) \\
\hline $\begin{array}{l}\text { Paramecium } \\
\text { caudatum }\end{array}$ & Protozoa & $2(100.0)$ & $0(0.0)$ & 2 & 1 & 1 (Ae. vitt.) \\
\hline Pleurotricha sp. & Protozoa & $1(100.0)$ & $0(0.0)$ & 1 & 1 & 1 (Ae. vitt.) \\
\hline $\begin{array}{l}\text { Allocrangonyx } \\
\text { pellucidus }\end{array}$ & Amphipoda & $1(50.0)$ & $1(50.0)$ & 2 & 2 & 1 (Ae. vitt.) \\
\hline Brachionus plicatilis & Rotatoria & $1(100.0)$ & $0(0.0)$ & 1 & 1 & $\begin{array}{l}3 \text { (An. gamb., CX. perf., CX. } \\
\text { simp.) }\end{array}$ \\
\hline Philodina sp. & Rotatoria & $3(100.0)$ & $0(0.0)$ & 3 & 2 & 1 (Ae. vitt.) \\
\hline Chydorus barroisi & Cladocera & $0(0.0)$ & $1(100.0)$ & 1 & 1 & 0 \\
\hline $\begin{array}{l}\text { Bosmina } \\
\text { longirostris }\end{array}$ & Cladocera & $2(66.7)$ & $1(33.30)$ & 3 & 2 & 2 (Ae. vitt., An. gamb.) \\
\hline Daphnia pulex & Cladocera & $18(69.2)$ & $8(30.8)$ & 26 & 9 & $\begin{array}{l}4 \text { (Ae. vitt., An. gamb., CX. } \\
\text { perf., Cx. p. p.) }\end{array}$ \\
\hline $\begin{array}{l}\text { Diaphnosoma } \\
\text { birgei }\end{array}$ & Cladocera & $1(100.0)$ & $0(0.0)$ & 1 & 1 & 2 (Ae. vitt., Cx. p. p.) \\
\hline $\begin{array}{l}\text { Diaphnosoma } \\
\text { brachyurum }\end{array}$ & Cladocera & $1(100.0)$ & $0(0.0)$ & 1 & 1 & 2 (Ae. vitt., An. gamb.) \\
\hline $\begin{array}{l}\text { Laptonopsis } \\
\text { occidentali }\end{array}$ & Cladocera & $3(60.0)$ & $2(40.0)$ & 5 & 5 & 2 (Ae. vitt., Cx. p. p.) \\
\hline Macrothrix pulex & Cladocera & $1(100.0)$ & $0(0.0)$ & 1 & 1 & 2 (An. gamb., Cx. perf.) \\
\hline Macrothrix rosea & Cladocera & $2(50.0)$ & $2(50.0)$ & 4 & 4 & 2 (Ae. vitt., Cx. p. p.) \\
\hline $\begin{array}{l}\text { Moinodaphnia } \\
\text { macleayi }\end{array}$ & Cladocera & $1(100.0)$ & $0(0.0)$ & 1 & 1 & 1 (Ae. vitt.) \\
\hline Moina macrocopa & Cladocera & $12(75.0)$ & $4(25.0)$ & 16 & 7 & $\begin{array}{l}4 \text { (Ae. vitt., An. gamb., Cx. } \\
\text { perf., Cx. p. p.) }\end{array}$ \\
\hline Sida crystallina & Cladocera & $2(100.0)$ & $0(0.0)$ & 2 & 2 & $\begin{array}{l}3 \text { (Ae. viit., An. gamb., Cx. } \\
\text { perf.) }\end{array}$ \\
\hline $\begin{array}{l}\text { Candona } \\
\text { intermedia }\end{array}$ & Ostracoda & $1(100.0)$ & $0(0.0)$ & 1 & 1 & 2 (Ae. vitt., Cx. p. p.) \\
\hline Candona parallela & Ostracoda & $2(66.7)$ & $1(33.3)$ & 3 & 2 & $\begin{array}{l}5 \text { (Ae. vitt., An. gamb., Cx } \\
\text { perf., Cx. p. p., Cx. simp.) }\end{array}$ \\
\hline Cypria obesa & Ostracoda & $3(100.0)$ & $0(0.0)$ & 3 & 2 & $\begin{array}{l}3 \text { (Ae. vitt., An. gamb., Cx. } \\
\text { perf.) }\end{array}$ \\
\hline $\begin{array}{l}\text { Cypricercus } \\
\text { reticulatus }\end{array}$ & Ostracoda & $7(77.8)$ & $2(22.2)$ & 9 & 4 & $\begin{array}{l}4 \text { (Ae. vitt., An. gamb., Cx } \\
\text { mact., Cx. perf.) }\end{array}$ \\
\hline $\begin{array}{l}\text { Cyprinotus } \\
\text { incongruens }\end{array}$ & Ostracoda & $5(83.3)$ & $1(16.7)$ & 6 & 3 & $\begin{array}{l}3 \text { (Ae. vitt., An. gamb., Cx.p. } \\
\text { p.) }\end{array}$ \\
\hline $\begin{array}{l}\text { Potamocypris } \\
\text { hyboforma }\end{array}$ & Ostracoda & $5(100.0)$ & $0(0.0)$ & 5 & 2 & $\begin{array}{l}3 \text { (Ae. vitt., An. gamb., Cx. } \\
\text { macf.) }\end{array}$ \\
\hline Cyclops sp. & Copepoda & $3(100.0)$ & $0(0.0)$ & 3 & 1 & 4 (Ae. vitt., An. gamb.) \\
\hline Macrocyclops sp. & Copepoda & $2(100.0)$ & $0(0.0)$ & 2 & 1 & 2 (Ae. vitt., An. gamb.) \\
\hline Alaimus sp. & Nematoda & $4(57.1)$ & $3(42.9)$ & 7 & 6 & 2 (Ae. vitt., Cx.p.p) \\
\hline Diplogaster sp. & Nematoda & $0(0.0)$ & $1(100.0)$ & 1 & 1 & 0 \\
\hline Monhystera sp. & Nematoda & $27(67.5)$ & $13(32.5)$ & 40 & 11 & $\begin{array}{l}4 \text { (Ae. vitt., An. gamb., Cx. } \\
\text { perf., Cx. simp.) }\end{array}$ \\
\hline Rhabdolaimus sp. & Nematoda & $1(100.0)$ & $0(0.0)$ & 1 & 1 & 1 (Ae. vitt.) \\
\hline
\end{tabular}


Table 2 Microinvertebrates coinhabiting mosquito habitats in rock pools on inselbergs within Kaduna State, Nigeria (Continued)

\begin{tabular}{|c|c|c|c|c|c|c|}
\hline \multirow{2}{*}{$\begin{array}{l}\text { Microinvertebrate } \\
\text { species }\end{array}$} & \multicolumn{5}{|c|}{ No. collected(\%) } & \multirow{2}{*}{$\begin{array}{l}\text { No. of associated mosquito } \\
\text { species (abbreviated) }\end{array}$} \\
\hline & Class/order & $\begin{array}{l}\text { Microinvertebrates in } \\
\text { mosquito-positive pools }\end{array}$ & $\begin{array}{l}\text { Microinvertebrates in } \\
\text { mosquito-negative pools }\end{array}$ & Total & $\begin{array}{l}\text { No. of inselbergs } \\
\text { where found }\end{array}$ & \\
\hline Total & & $70(74.5)$ & $24(25.5)$ & 94 & 45 & \\
\hline
\end{tabular}

Ae. vitt., Aedes vittatus; An. gamb., Anopheles gambiae; Cx. perf., Culex perfidiosus; CX. p.p., Culex pipiens pipiens; CX. simp., Culex simpsoni

Mosquito larvae face a number of threats, including predation and desiccation of habitats, and mosquitoes are typically characterized by rapid completion of the life cycle (Clark, Flis, \& Remold, 2004). This without doubt was evident on Kufana inselberg which recorded zero abundance of mosquito larva for the number of sampled pools. These rock pools were maintained exclusively by rainfall which within 3 to 4 days becomes suitable habitats for mosquitoes and microinvertebrates. This supported the proposition by Okogun, Anosike, Okere, and Nwoke (2005) that the composition and density of larval mosquito communities are strongly influenced by the ephemeral nature of the pool. Since rock pools communities are completely dependent on the length and frequency of inundations, the active community reflects the prevailing weather conditions (Jocque, Vanschoenwinkel, \& Brendonck, 2010). Danmagaji and Kufena inselbergs recorded relatively low abundance of mosquito larvae compare to abundance of mosquito larvae from other inselbergs. However, lurches of rainfall during the preliminary stage of this work left some of the pools on the rocks with freshly filled rainwater without mosquito larva. Similarly, rainless (break) period towards June ending may have accounted for the low volume or absence of waters in majority of rock pools and invariably the low population or absence of mosquito larvae particularly. The present study agreed with Ranta (1982) who observed that rock pool organisms can either have to escape from the habitat when conditions deteriorate or spend the unfavourable period in some kind of dormant forms.

Cladocerans, the dominant microinvertebrtes coinhabiting rock pools with mosquito larvae and other zooplankton communities can live, and attain high densities in these ephemeral wetlands (Glime, 2017; Knight, Chase, Goss, \& Knight, 2004). This is because many species of zooplankton have adapted to deal with wetland drying. Specifically, they can lay resting eggs that remain dormant while the wetland is dry and then hatch when the wetland is filled with water again. Almost all the microinvertebrates recorded in this study undergo similar trend of surviving the ephemeral nature of the rock pool microhabitats during unfavourable condition and eventually serve as mosquito food organisms, competitors, and/or predators when the condition becomes favourable. This explains the continuing patterns of mosquito abundance and possible break out of mosquito-borne diseases. Microorganisms and particulate organic detritus generally constitute the major part of larval mosquito diets. Although most reports suggest that mosquito larvae are not very discriminatory in the types of food they ingest, laboratory studies indicate that limited sizes of particles are ingested. This selection may be a result of morphological and behavioural adaptations for acquiring food, instar-specific features, and particle shape and texture (Merritt et al., 1992). Many species of protozoa and rotifers are $50-250 \mu \mathrm{m}$ in length, a size range that coincides with waterborne particles ingested by filter-feeding mosquito larvae (Linenberg et al., 2016). Protozoa particularly occupy the mid-trophic levels of freshwater ecosystems. They consume bacteria and are important prey for mosquito larvae (Eisenberg, Washburn, \& Schreiber, 2000).

Mosquito larvae tolerate a wide spectrum of physiochemical parameters which play major role in their distribution. Range of physicochemical factors and biotic factors (e.g. competition) influences species assemblage in temporary pools. Aquatic organisms are sensitive to temperature, dissolved oxygen, $\mathrm{pH}$, etc. and are mainly influenced by climatic variation (Whalen, Duffy, \& Grace, 2013). The present study observed an overall wide temperature range slightly above the optimum temperature $\left(31^{\circ} \mathrm{C}\right)$ considered for rapid larval and pupal development (Oyewole et al., 2009). This apparent temperature increase over the optimum within the rock pools could be attributed to height and exposure of the inselberg above the ground positioning the pools to direct incident radiation from the sun. In addition, the granitic nature of the inselbergs allows for rapid absorption and retention of heat from the sun. Jocque et al. (2010) observed that water temperature in rock pools depends on climate and seldom exceeds $40^{\circ} \mathrm{C}$ because of the balance between cooling through evaporation and heating by insolation. Zooplankton communities often vary in composition as certain species are highly sensitive to changes in nutrient cycling, temperature, and variable environmental conditions (Loria, 2017). The rapid increase in anthropogenic activities on most of the inselbergs necessitated influx of nutrients into these pools as indigenes utilize the surface of the rock for sun drying of multitudes of their harvested proceeds. The indirect consequences of this usage attract domestic goats and other domestic ruminants on the rock. Excreta from these domestic animals can be a 


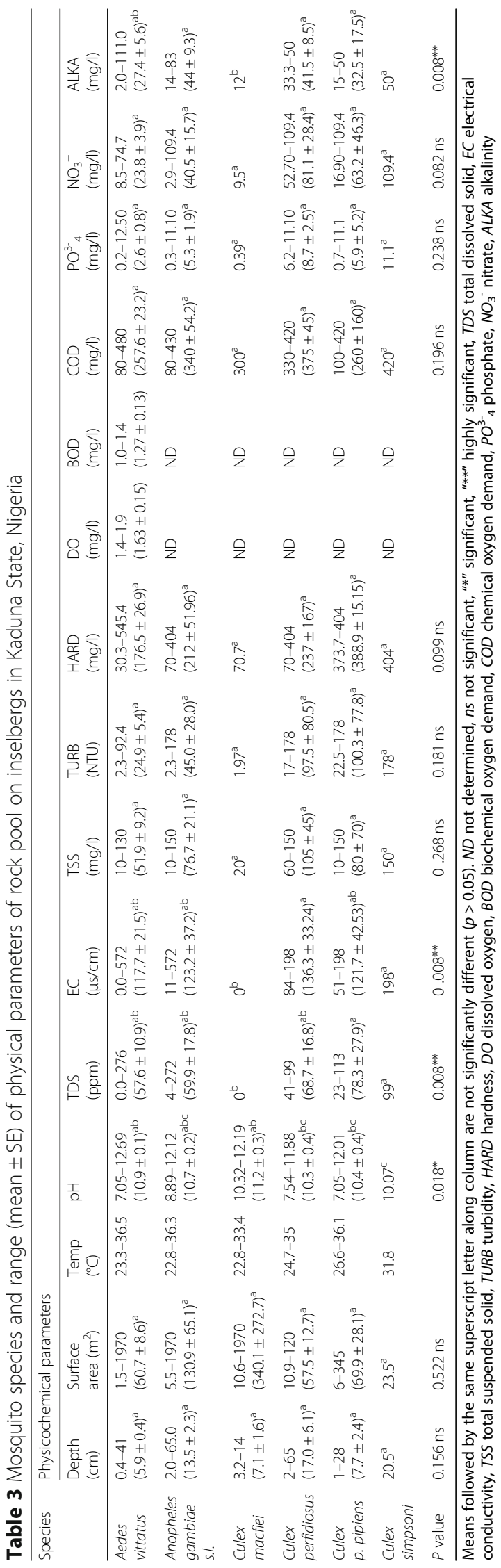




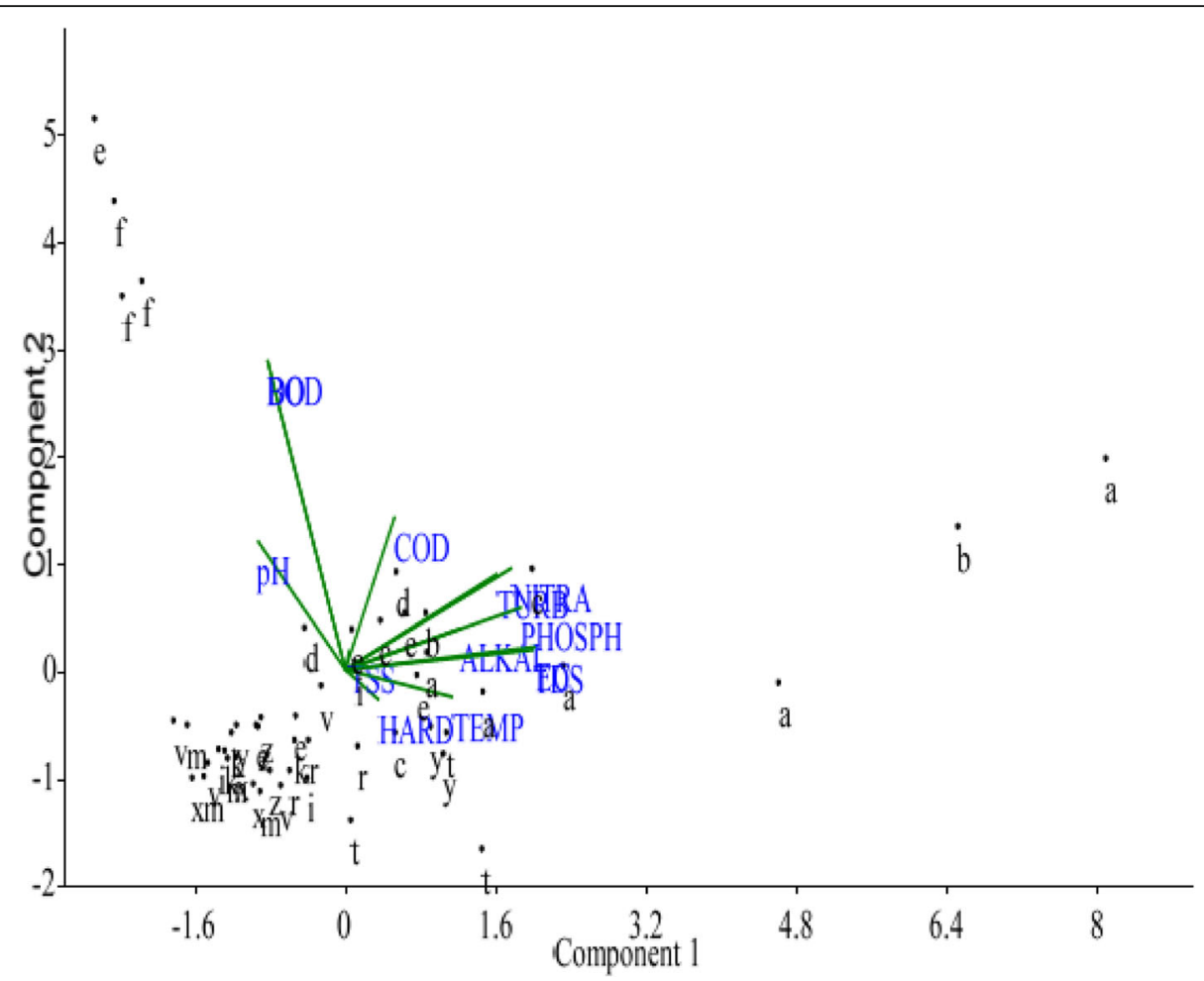

Fig. 2 Interaction effect of the physicochemical parameters of the rock pools amongst the inselbergs. Key: a, Dumbi; b, Danmagaji; c, Hanwa; $d$, Dutsen-Abba; e, Kufena; f, Wusasa; g, Zango-Aya; i, Kujama; k, Tudu-Mare; m, Kagoma; r, Kajuru; t, Jere; v, Kwoi; x, Nok; y, Chori; z, Samban-Gida

significant source of nitrogen and phosphorus into aquatic habitats and strongly influence the structure and functioning of the plankton community. Communities with more species take greater advantage of niche opportunities and capture a greater proportion of biologically available resources, like nitrogen or phosphorus, and that certain species of cladocerans are especially sensitive to increased phosphorus (Loria, 2017). Nutrients such as nitrate, phosphorus, and alkalinity declined quickly in temporary pools because of nutrient uptake by organisms and a reduced rate of nutrient supply from the sediment (Jocque et al., 2010). Immediately after filling, dissolved nitrogen and phosphorus concentrations may be quite high but nutrients in the sediment get into the water via bioturbation of some crustaceans. Habitats with large surface areas tend to have higher immigration and often offer a wider range of microhabitats/niches and decreased local extinction, which result in higher species diversity. Therefore, the active avoidance of habitats by oviposition of adult female mosquitoes with the aid of semiochemicals emitted from predators may ultimately act to sustain high densities of mosquito larvae in the rock pools. Daniel and Boyden (1975) and Huggett and Griffiths (1986) relate oxygen concentration as one of the most important parameters controlling community structure in rock pools. Electrical conductivity (EC) and total dissolved solid (TDS) obtained in this study were largely below detectable limit with the HANNA instrument. This corroborates the report of Ranta (1982) that the small nature of the volume of water in rock pools results in strong fluctuation in electrical conductivity. Jocque et al. (2010) also observed that rock pools were characterized by low conductivity immediately after filling, typically fluctuating between 10 and $30 \mu \mathrm{S} \mathrm{cm}^{-1}$. As the water evaporates, conductivity increases mainly because of the concentration of metabolites and can reach values up to $1400 \mu \mathrm{S} \mathrm{cm}^{-1}$ in pools with the longest hydroperiod (Jocque et al., 2010). In this study, strong alkalinity may be a strong indicator for the diversity of microinvertebrates and mosquito larvae in their choice of breeding in rock pool habitats. Clements (1963) showed that a balance in an ecosystem was maintained when $\mathrm{pH}$ was within the range of 5.5 to 8.5. Increased surface $\mathrm{pH}$ in the rock pools could be due to increased metabolic activities of autotrophs, since they generally utilize the carbon dioxide and liberate oxygen, thus reducing $\mathrm{H}^{+}$ion concentration.

\section{Conclusions}

This study revealed the coinhabitation of microinvertebrates and breeding of mosquito larvae in rock pools. 
Microinvertebrates are partly potential food organisms, competitors, and/or potential mosquito predators. Mosquito predatory roles of the potential predators need to be ascertained in order to explore their real biological control potentials against noxious species of mosquito and consequently prevent potential outbreaks of mosquito-borne diseases. Succession pattern of rock pool communities needs to be unravelled to expose the interaction of abiotic factors as it relates to food chain and food web nature of rock pool communities.

\section{Abbreviations}

*: Significant; **: Highly significant; ALKA: Alkalinity; BOD: Biochemical oxygen demand; COD: Chemical oxygen demand; DO: Dissolved oxygen; EC: Electrical conductivity; HARD: Hardness; ND: Not determined; $\mathrm{NO}_{3}$ : Nitrate; ns: Not significant; $\mathrm{PO}_{3}$ : Phosphate; TDS: Total dissolved solid; TSS: Total suspended solid; TURB: Turbidity

\section{Acknowledgements}

The authors are thankful to the field assistants who helped in the sample collection within Kaduna State. We are also grateful to the village heads who granted access to climb and sample their inselbergs in the study area.

\section{Authors' contributions}

OAO conceptualized and designed the work. OAO analysed and interpret the data. OAO drafted the manuscript while $I H N$ and DAA substantively revised the drafted manuscript. All authors approved the submitted version of the manuscript.

\section{Funding}

This research did not receive any specific grant from funding agencies in the public, commercial, or not-for-profit sectors.

\section{Availability of data and materials}

Not applicable.

\section{Competing interest}

The authors declare that they have no competing interests.

\section{Ethics approval}

Not applicable.

\section{Consent for publication}

Not applicable.

\section{Author details}

'Department of Zoology, Federal University of Agriculture, Makurdi, Benue State, Nigeria. ${ }^{2}$ Department of Zoology, Ahmadu Bello University, Zaria, Kaduna State, Nigeria.

Received: 31 March 2019 Accepted: 12 July 2019

Published online: 06 August 2019

\section{References}

Adebote, D. A., Oniye, S. J., \& Muhammed, Y. A. (2008). Studies on mosquitoes breeding in rock pools on inselbergs around Zaria, northern Nigeria. Journal of Vector Borne Diseases, 45, 21-28.

American Public Health Association (1998). Standard methods for the examination of water and wastewater, (20th ed., ). Baltimore: United Book Press, Inc.

Andrade, M. R. (2015). Container-dwelling mosquitoes: habitat size, direct and indirect effects of predation, (pp. 10-15). Ph.D dissertation, Federal University of Vicosa, Brazil.

Beketov, M. A., Yurchenko, Y. A., Belevich, O. E., \& Liess, M. (2010). What environmental factors are important determinants of structure, species richness, and abundance of mosquito assemblages? Journal of Medical Entomology, 47, 129-139.

Chase, J. M., \& Knight, T. M. (2003). Drought-induced mosquito outbreaks in wetlands. Ecology Letters, 6, 1017-1024.
Clark, T. M., Flis, B. J., \& Remold, S. K. (2004). Differences in the effects of salinity on larval growth and developmental programs of a freshwater and a euryhaline mosquito species (Insecta: Diptera, Culicidae). Journal of Experimental Biology, 207, 2289-2295.

Clements, A. N. (1963). The physiology of mosquitoes: Relationship of plankton to anopheline larvae, (pp. 68-310). Oxford: Pergamon Press.

Daniel, M. J., \& Boyden, C. R. (1975). Diurnal variations in physico-chemical conditions within intertidal rock pools. Field Studies, 4, 161-176.

Duquesne, S., Kroeger, I., Kutyniok, M., \& Liess, M. (2011). The potential of cladocerans as controphic competitors of the mosquito Culex pipiens. Journal of Medical Entomology, 48, 554-560.

Eisenberg, J. N. S., Washburn, J. O., \& Schreiber, S. J. (2000). Generalist feeding behaviours of Aedes sierrensis larvae and their effects on protozoan populations. Ecology, 81(4), 921-935.

Fischer, S., Zanotti, G., Castro, A., Quiroga, L., \& Vargas, D. V. (2013). Effect of habitat complexity on the predation of Buenoa fuscipennis (Heteroptera: Notonectidae) on mosquito immature stages and alternative prey. Journal of Vector Ecology, 38(2), 215-223.

Gillies, M.T. and Coetzee, M. (1987). A supplement to the Anophelinae of Africa South of Sahara. South African Institute for Medical Research, p55.

Gillies, M.T. and DeMeillon, B. (1968). The Anophelinae of South Africa South of Sahara (Ethiopian Zoogeographical Region). South African Institute for Medical Research, 54:343.

Glime, J. M. (2017). Arthropods: Crustacea - Copepoda and Cladocera. Ecology, 2, $1-10$.

Hopkins, G.H.E. (1952). Mosquitoes of the Ethiopian region I -Larval bionomics of mosquitoes and taxonomy of culicine larvae. British Museum (Natural History), London. p355.

Huggett, J., \& Griffiths, C. L. (1986). Some relationships between elevation, physico- chemical variables and biota of intertidal rock pools. Marine EcologyProgress Series, 29, 189-197.

Jocque, M., Vanschoenwinkel, B., \& Brendonck, L. (2010). Freshwater rock pools: A review of habitat characteristics, faunal diversity and conservation value. Freshwater Biology, 55, 1587-1602.

Kaufman, M. G., Goodfriend, W., Kohler-Garrigan, A., Walker, E. D., \& Klug, M. J. (2002). Soluble nutrient effects on microbial communities and mosquito production in Ochlerotatus triseriatus habitats. Aquatic Microbial Ecology, 29, 73-88.

Knight, T. M., Chase, J. M., Goss, C. W., \& Knight, J. J. (2004). Effects of interspecific competition, predation, and their interaction on survival and development time of immature Anopheles quadrimaculatus. Journal of Vector Ecology, 29(2), 277284.

Kroeger, I., Liess, M., Dziock, F., \& Duquesne, S. (2013). Sustainable control of mosquito larvae in the field by the combined actions of the biological insecticide Bti and natural competitors. Journal of Vector Ecology, 38(1), 82-89.

Liess, M., Kroeger, l., \& Duquesne, S. (2014). Temporal and spatial habitat preferences and biotic interactions between mosquito larvae and antagonistic crustaceans in the field. Journal of Vector Ecology, 39(1), 103-111.

Linenberg, l., Christophides, G. K., \& Gendrin, M. (2016). Larval diet affects mosquito development and permissiveness to Plasmodium infection. Europe PMC, 6, 38230 .

Loria, K. (2017). Freshwater zooplankton communities as indicators of habitat quality: Testing responses to multiple disturbances. Undergraduate Honors Theses, (p. 1388) https://scholar.colorado.edu/honr_theses/1388.

Merritt, R. W., Dadd, R. H., \& Walker, E. D. (1992). Feeding behaviour, natural food, and nutritional relationships of larval mosquitoes. Annual Review of Entomology, 37, 349-376.

Meyabeme Elono, A. L., Liess, M., \& Duquesne, S. (2010). Influence of competing and predatory invertebrate taxa on larval populations of mosquitoes in temporary ponds of wetland areas in Germany. Journal of Vector Ecology, 35, 419-427.

Nigerian Arts and Culture Directory Project, 2013. Retrieved 10 Aug 2013 at 10:30 am from (http//:www.kadunastate.gov.ng/user_contentphp).

National Population Commission (NPC) (2006). Retrieved August 10, 2013 at 10:30 am from http://www.kadunastate.gov.ng/user_contentphp.

Okogun, G. R. A., Anosike, J. C., Okere, A. N., \& Nwoke, B. E. B. (2005). Ecology of mosquitoes of mid-western Nigeria. Journal of Vector Borne Diseases, 42, 1-5.

Oyewole, I. O., Momoh, O. O., Anyasor, G. N., Ogunnowo, A. A., Ibidapo, C. A.t Oduola, O. A., ... Awolola, T. S. (2009). Physico-chemical characteristics of 
Anopheles breeding sites: Impact on fecundity and progeny development. African Journal of Environmental Science and Technology, 3(12), 447-452.

Pennak, R. W. (1953). Freshwater invertebrates of the United States, (p. 769). New York: The Ronald Press Company.

Pialoux, G., Gaüzère, B., Jauréguiberry, S., \& Strobel, M. (2007). Chikungunya, anepidemic arbovirosis. The Lancet Infectious Diseases, 7(5), 319-327.

Ranta, E. (1982). Animal communities in rock pools. Annale Zoologici Fennici, 19, 337-347.

Rueda, L. M. (2007). Global diversity of mosquitoes (Insecta: Diptera: Culicidae) in freshwater. Hydrobiologia, 595, 477-482.

Service, M. W (1976). Mosquito ecology field sampling methods, (pp. 76-77). London: Applied Science Publishers Limited.

Service, M. W (1992). Importance of ecology in Aedes aegypti control. Asian Journal of Tropical Medicine and Public Health, 23, 681-688.

Whalen, M. A., Duffy, J. E., \& Grace, J. B. (2013). Temporal shifts in top-down vs. bottom-up control of epiphytic algae in a seagrass ecosystem. Ecology, 94(2), 510.

Yee, D. A., Kesavaraju, B., \& Juliano, S. A. (2004). Larval feeding behaviour of three co-occuring species of container mosquitoes. Journal of Vector Ecology, 29(2), 315-322

\section{Publisher's Note}

Springer Nature remains neutral with regard to jurisdictional claims in published maps and institutional affiliations.

\section{Submit your manuscript to a SpringerOpen ${ }^{\circ}$ journal and benefit from:}

- Convenient online submission

- Rigorous peer review

- Open access: articles freely available online

- High visibility within the field

- Retaining the copyright to your article

Submit your next manuscript at $\boldsymbol{\nabla}$ springeropen.com 